\title{
Characterising the water use and hydraulic properties of riparian tree invasions: A case study of Populus canescens in South Africa
}

\author{
Z Ntshidi',2*, MB Gush', S Dzikiti ${ }^{1,2}$ and DC Le Maitre ${ }^{1}$ \\ ${ }^{1}$ Natural Resources and the Environment, Council for Scientific and Industrial Research, 11 Jan Cilliers Street, 7599, Stellenbosch South Africa \\ ${ }^{2}$ Institute for Water Studies, Department of Earth Sciences, University of the Western Cape, South Africa
}

\begin{abstract}
Invasive alien plants (IAPs) pose a serious threat to the already limited water resources in dry countries like South Africa which are facing increasing water shortages. Much of South Africa is expected to get drier in future due to climate change. In addition, the future climatic conditions are also predicted to accelerate the rate at which IAPs will spread, due to favourable growing conditions, further disrupting the provision of goods and services. Previous studies on tree water use in South Africa focused on commercial forests of introduced genera mainly Pinus, Eucalyptus, and Acacia. This study sought to expand these observations by quantifying water use and its drivers in riparian Grey Poplar (Populus canescens) invasions in the Berg River catchment of South Africa. Whole tree hydraulic resistance ranged from $~ 1.4 \mathrm{MPa} \cdot \mathrm{h} \cdot \mathrm{g}^{-1}$ for large trees to $\sim 14.3 \mathrm{MPa} \cdot \mathrm{h} \cdot \mathrm{g}^{-1}$ for the small ones. These resistances are higher than those found for poplars in temperate climates, suggesting substantial hydraulic constraints to transpiration. Daily peak transpiration varied from 5 to $6 \mathrm{~L} \cdot \operatorname{tree}^{-1}$ in small trees $(\sim 9.2 \mathrm{~cm} \mathrm{DBH})$ to between 35 and $40 \mathrm{~L} \cdot$ tree $^{-1}$ for large trees $(24 \mathrm{~cm} \mathrm{DBH})$. Stand-level transpiration peaked at $\sim 4 \mathrm{~mm} \cdot \mathrm{d}^{-1}$ in summer (JanFeb). However, the annual total transpiration was only $338 \mathrm{~mm}$ due to the deciduous nature of the species and also the high hydraulic resistance in the transpiration stream. Daily transpiration was strongly correlated to solar radiation $\left(R^{2}>0.81\right)$ while the air vapour pressure deficit (VPD) constrained transpiration at high VPD values. We conclude that the water use of the poplar invasions is significantly lower than that of other riparian invasions. The impact of these invasions on the water resources is therefore likely quite low, warranting less priority in alien plant clearing operations aimed at salvaging water.
\end{abstract}

Keywords: climate, hydraulic resistance, poplar, transpiration

\section{INTRODUCTION}

The total area infested by invasive alien plants (IAPs) in South Africa is over $100000 \mathrm{~km}^{2}$ (Le Maitre et al., 2016; Van Wilgen et al., 2001) which is over $8 \%$ of the country's total area. These invasions are mostly concentrated in the wetter parts of the country which are key sources of water for the country's major rivers. A lot of the invasions also grow along river channels and in floodplains, thereby directly affecting stream flows (Scott and Prinsloo, 2008) and groundwater sources (Clulow et al., 2011). A substantial portion of South Africa is expected to get drier in future due to climate change (Midgley et al., 2003), especially the Southwestern Cape Region. Exacerbating the effects of the invasions in these regions is the fact that the new climatic conditions are predicted to accelerate the rate at which IAPs will spread (Richardson and Van Wilgen, 2004), exceeding the current rate of $\sim 5 \%$ per annum (Le Maitre et al., 2000).

In the past, the majority of tree water-use studies in South Africa focused on single-species commercial plantations of introduced tree genera such as Pinus, Eucalyptus and Acacia (Gush et al., 2002; Dye and Versfeld, 2007; Scott and Prinsloo, 2008; Clulow et al., 2011). A few recent studies have established the water use by these, and other species, outside plantations, in areas where the species are invasive. These include $A$. mearnsii (Dye et al., 2008), Pinus halepensis (Dzikiti et al., 2013a), Prosopis spp. (Dzikiti et al., 2013b; Ntshidi et al., 2015), and Eucalyptus camaldulensis (Dzikiti et al., 2016). However,

To whom all correspondence should be addressed.

푤 $+27+27$ (0)21 888 2639; fax: +27 (0)21 888 2682;

e-mail: zntshidi@csir.co.za or zntshidi@myuwc.ac.za

Received 11 April 2017; accepted in revised form 10 April 2018 information gaps still remain on the water use and hydrological impacts of key species such as Populus canescens (P. canescens) and willows (Salix species), which constitute a combined $12.1 \%$ of the invaded area in South Africa (Van Wilgen, 2008).

This study therefore seeks to close this information gap by focusing on the water use of $P$. canescens invasions in the Berg River catchment of the Western Cape Province, South Africa. Besides the paucity of information on water use by IAPs, few studies provide quantitative information on the factors that limit water use by invasive alien plants. Calder and Dye (2001), for example, identified 6 controls and limits on water use by vegetation. These include: radiation, advection, soil moisture, tree size, drop size, and physiological factors. In this study we investigate, in detail, some of these limiting factors for poplars which have ready access to stream water year-round. We specifically investigate the role of various climate driving variables and physiological factors, principally the hydraulic characteristics of the transpiration stream of the invasions. The values obtained are subsequently compared with those found in other climatic regions.

The hydraulic resistance, for example, is an important measure of the efficiency with which trees take up water. It influences transpiration rates, particularly the balance between root water uptake and leaf transpiration (Jones, 1990). Hydraulic capacitance, on the other hand, gives an indication of the ability of trees to store water for later use, e.g., when water supply does not match demand (Steppe et al., 2006). A recent study by Pfautsch et al. (2016) suggests that prevailing climatic conditions play a critical role in the hydraulic properties of species and this, in turn, determines the volumes of water used by the plants.

The specific objectives of this study were to: (i) quantify the diurnal and seasonal water use characteristics of riparian 
P. canescens invasions; (ii) establish how climate driving factors affect transpiration rates of the poplars, and; (iii) determine the hydraulic properties of the poplars under the semi-arid Mediterranean climatic conditions and to establish the likely implications for water use by the invasions.

\section{MATERIALS AND METHODS}

\section{Study site}

The study was done along the Franschhoek River, which is a perennial tributary of the upper Berg River, on Eikenhof Farm $\left(33.884334^{\circ} \mathrm{S}\right.$ and $19.060978^{\circ} \mathrm{E}$, elevation $190 \mathrm{~m}$ amsl). The site is about $6 \mathrm{~km}$ to the west of Franschhoek town in the Western Cape Province of South Africa (Fig. 1), and comprised of dense invasions of $P$. canescens of varying age-groups, with the tallest trees exceeding $10 \mathrm{~m}$. A survey of a $10 \mathrm{~m} \times 60 \mathrm{~m}$ plot $\left(600 \mathrm{~m}^{2}\right)$ yielded 56 P. canescens trees translating to a tree density of approximately 933 plants.ha ${ }^{-1}$. Stem diameters at breast height (DBH) of the trees ranged from $9.2 \mathrm{~cm}$ for small trees to $24 \mathrm{~cm}$ for the largest trees. Small trees were dominant, comprising $233.9 \%$ of the total population with a mean stem size for the stand of approximately $17 \mathrm{~cm}$. A number of understorey indigenous species, notably Wild Peach (Kiggelaria africana), also grew as scattered individuals in the stand. Soils at the site were predominantly deep sandy soils interspersed with dark-red clayey loam soils. There were a number of stream-side boulders lining the stream channel.
The adjacent farmland on either side of the river, situated less than $20 \mathrm{~m}$ from the trees, was planted to vines under drip irrigation. The climate of the study area is Mediterranean with most of the rain falling in winter (May to August), with a long-term average rainfall of $\sim 863 \mathrm{~mm} \cdot \mathrm{a}^{-1}$. The long-term average temperature is $18.9^{\circ} \mathrm{C}$ with maximum and minimum temperatures of 42.5 and $1.02^{\circ} \mathrm{C}$, respectively. Poplar is a deciduous tree species. In South Africa new leaves develop in early spring, around September, and peak canopy cover is reached in summer in early to mid-November. Senescence and leaf fall occur at the beginning of winter in May.

\section{Climate, transpiration and growth measurements}

Data were collected from the study site over one calendar year from February 2015 to February 2016. Transpiration was measured using the heat ratio method of the heat pulse velocity (HPV) sap flow technique (Burgess et al., 2001) on 3 trees with different stem diameters at breast height $(\mathrm{DBH})$. The sap flow rates were measured hourly throughout the study. A metal template with 3 holes spaced $6 \mathrm{~mm}$ apart was used to drill the holes to minimize probe misalignment. The sap flow monitoring system comprised a data logger (Model CR1000, Campbell Scientific, Inc., Logan UT, USA), a multiplexer (Model AM16/32B; Campbell Scientific, Inc., Logan UT, USA), a custommade relay control module, a 70 Ah battery, 12 heaters and 12 T-type (copper-constantan) thermocouple pairs.

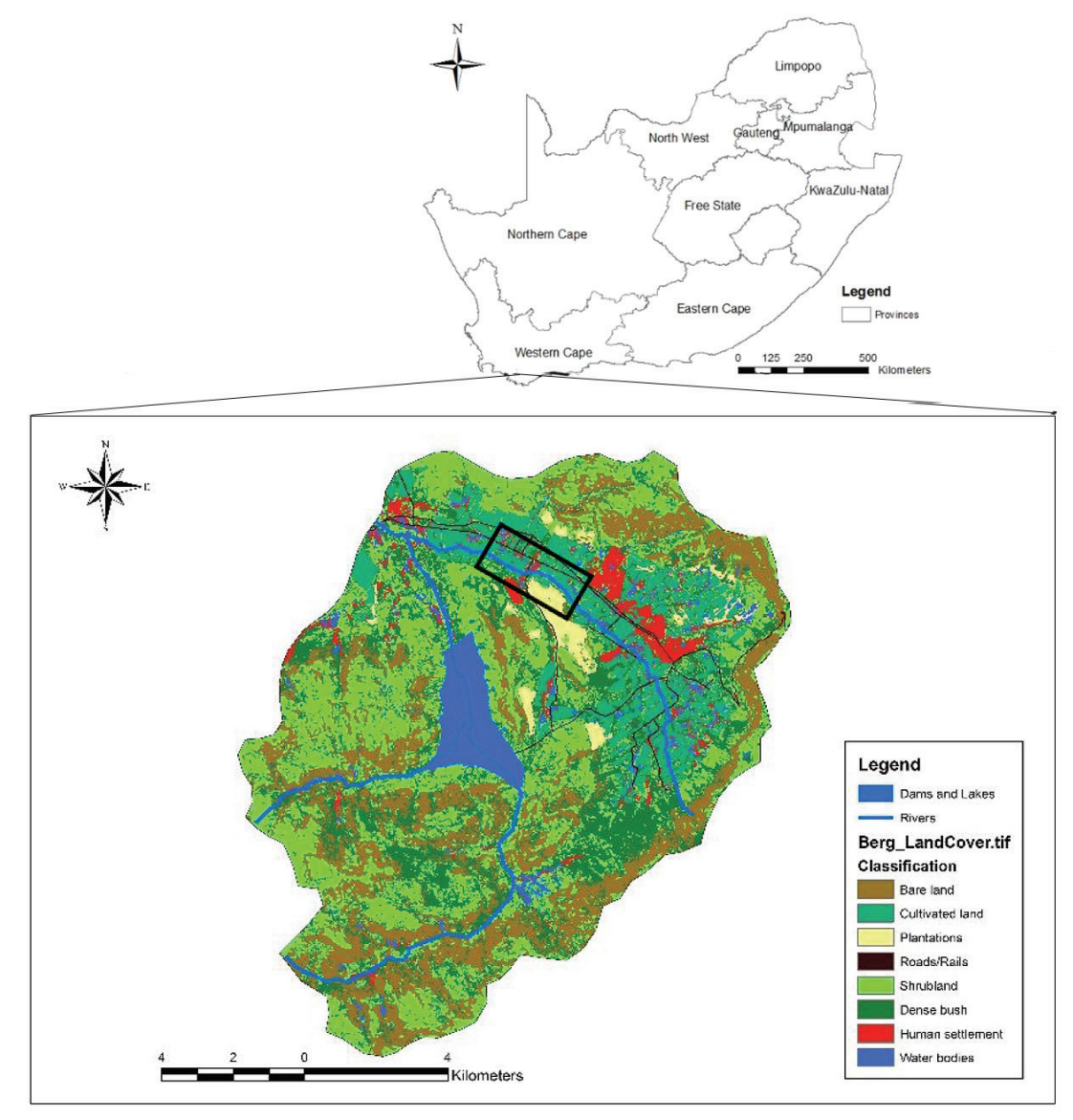

Figure 1

Map of South Africa showing the land cover around the study area near the town of Franschhoek in the Western Cape Province of South Africa. Data was collected in the area enclosed by the black rectangle in the insert. 
The thermocouples were installed at several depths into the sapwood, ranging from 10 to $24 \mathrm{~mm}$, in each stem in the four cardinal directions to capture the circumferential and radial variation in sap velocity (Wullschleger and King, 2000). Methylene blue dye was injected in the stems to determine the extent of the active xylem vessels (sapwood depth) where the thermocouples were positioned. The average bark thickness was about $5 \mathrm{~mm}$ while the wood density of the stem averaged $0.465 \mathrm{~g} \cdot \mathrm{cm}^{-3}$ and the wood moisture fraction was about $43 \%$. The sap flow data was corrected for wounding according to the approach described by Swanson and Whitfield (1981). The instrumented trees were growing less than $5 \mathrm{~m}$ from the river channel. Therefore, it is highly likely that they had access to river water given that the lateral root systems of the poplars can extend more than $10 \mathrm{~m}$ away from the main stem. The leaf area index (LAI) $\left(\mathrm{m}^{2}\right.$ of leaf area per $\mathrm{m}^{2}$ of ground area) of the stand was recorded using an LAI-2000 plant canopy analyser (Li-Cor., Inc., Lincoln, Nebraska, USA). Leaf area index measurements were taken at 2-weekly intervals at the start of the growing period and less frequently (once in 2 months) during the rest of the growing season.

Hourly weather data were obtained from an automatic weather station managed by the Agricultural Research Council (ARC) located at a nearby farm (La Motte), which was less than $3 \mathrm{~km}$ from the study site. Variables monitored included solar radiation, air temperature, relative humidity, wind speed and direction, and rainfall. The weather station was located on a short grass surface in an open space away from obstructions. Most of the sensors were installed at the standard height of $2.0 \mathrm{~m}$ above the ground.

\section{Evaporation, soil and tree water status}

The volumetric soil water content was monitored hourly at $15 \mathrm{~cm}$ depth throughout the study using time domain reflectometers (Model CS616, Campbell Scientific, Inc., USA). The CS616 sensors were connected to the CR1000 data logger. Additional hourly data of soil evaporation, open water evaporation from the stream, and leaf water potential were collected manually on selected clear days in late spring (October 2015), and early and late summer in December 2015 and February 2016, respectively. Soil evaporation was measured using 4 micro-lysimeters situated in areas having different shading conditions and distance from the river channel. Open water evaporation was measured using 2 evaporimeters located in the middle of the stream channel, while a Scholandertype pressure chamber (Model: 615 PMS Instrument Company, Albany, OR, USA) was used to measure the leaf water potential hourly. Four mature, healthy and fully expanded leaves were selected and used for the leaf water potential measurements. Two of the leaves were sun-exposed while the other two were shaded. Detailed hourly measurements of evaporation from the forest floor and from the open water in the river channel were made on 4 occasions, namely: 17 August 2015 (late winter), 6 October 2015 (late spring), 17 December 2015 and 4 February 2016 (summer).

\section{RESULTS AND DISCUSSION}

\section{Microclimate}

Daily data for Eikenhof Farm for a full year showed the typical seasonal trends in climatic variables, i.e., maximum (Tmax) and minimum temperatures (Tmin), solar radiation, average wind speed and rainfall (Fig. 2). Data were missing



Figure 2

Daily weather data for the P. canescens invaded site near Franschhoek 
between October and November 2015 due to equipment failure on the automatic weather station at La Motte. However, suitable data from another automatic weather station on a nearby farm (Bien Donne) were obtained from the ARC for this period and the missing data were patched. Correlations were established between the weather variables at the two stations and the resulting regression equations were used to gap-fill the missing data.

Maximum daily air temperature peaked at $43^{\circ} \mathrm{C}$ during late summer in March 2015 while the lowest minimum temperature of $1.03^{\circ} \mathrm{C}$ was recorded in July 2015 . The highest monthly rainfall recorded during the study period was $161 \mathrm{~mm}$ in June and $164 \mathrm{~mm}$ in July 2015, respectively. Total rainfall during the study period amounted to $606 \mathrm{~mm}$ which was approximately half of the reference evapotranspiration of over $1120 \mathrm{~mm}$ over the same period. The annual rainfall was also lower than the long-term average for the site ( $\sim 863 \mathrm{~mm})$, consistent with the drought experienced in the Western Cape Province during the study period. The reference evapotranspiration (ETo) was calculated using the modified Penman-Monteith equation for a short grass reference that is healthy and actively growing, according to Allen et al. (1998). Daily average solar radiation values ranged from $24.3 \mathrm{MJ} \cdot \mathrm{m}^{-2} \cdot \mathrm{d}^{-1}$ in February 2015 (summer) to as low as $7.5 \mathrm{MJ} \cdot \mathrm{m}^{-2} \cdot \mathrm{day}^{-1}$ in winter (June 2015), rising to a peak of up to $28.4 \mathrm{MJ} \cdot \mathrm{m}^{-2} \cdot \mathrm{d}^{-1}$ in December 2015 . Wind speeds were generally low and averaged $0.9 \mathrm{~m} \cdot \mathrm{s}^{-1}$, peaking at a daily average of $1.1 \mathrm{~m} \cdot \mathrm{s}^{-1}$ between January and March 2015 (Table 1).

\section{Eco-hydrological measurements}

Sap flow (water-use) volumes recorded in the P. canescens trees illustrate the highly seasonal nature of the transpiration dynamics associated with this deciduous species (Fig. 3). Transpiration rates were highest in the summer months, declining rapidly in autumn to early winter, between April and May, as the trees shed their leaves and as the atmospheric evaporative demand dropped. No sap flow was detectable between mid-May and the end of September when the trees were leafless. Sap flow resumed shortly after the first flush of spring leaves in September. The seasonal variation in transpiration was consequently attributable primarily to the deciduous nature of this species and the seasonal changes in the atmospheric evaporative demand. The trees likely transpired at the maximum rates given the proximity of the trees to the stream channel.

Daily transpiration volumes in the instrumented trees peaked at between 5 and $6 \mathrm{~L}$ for the smallest tree (Tree $2 \sim 9.2 \mathrm{~cm} \mathrm{DBH}$ ), 15 to $20 \mathrm{~L}$ for the medium-sized tree (Tree $1 \sim 16.2 \mathrm{~cm} \mathrm{DBH}$ ), and 35 and $40 \mathrm{~L}$ for the largest tree (Tree $3 \sim 24 \mathrm{~cm} \mathrm{DBH}$ ). Annual transpiration totals for the 3 study trees were weighted according to the number of trees in the size class that they represented (based on the stand stem diameter survey). A single transpiration rate for the stand was determined accounting for variations in stem diameter across the study site (Table 2). Individual tree transpiration volumes $\left(\mathrm{L} \cdot \mathrm{yr}^{-1}\right)$ were also scaled up to weighted stand equivalent depths of water-use $\left(\mathrm{mm} \cdot \mathrm{yr}^{-1}\right)$ using the stand sapwood area index ( $\mathrm{m}^{2}$ of sapwood per $\mathrm{m}^{2}$ of ground area). The large instrumented tree (Tree 3) transpired between 6000 and $7000 \mathrm{~L} \cdot \mathrm{yr}^{-1}$ compared to about $1000 \mathrm{~L} \cdot \mathrm{yr}^{-1}$ for the smallest instrumented tree (Tree 2).

Daily stand-level transpiration rates for the poplar-invaded site peaked at about $4.0 \mathrm{~mm}$ during the hot and dry summer weather. However, the annual transpiration was only $338 \mathrm{~mm}$ from February 2015 to February 2016. This figure is fairly low compared to the annual transpiration rates reported for other riparian invasions. For example, Dzikiti et al. (2013a) measured the annual total transpiration of Pinus halepensis invasions at a montane site about $25 \mathrm{~km}$ from the current study area to be about 3 times higher than that by the poplars, at $980 \mathrm{~mm}$. In another study further downstream on the Berg River, the annual total transpiration by Eucalyptus camaldulensis trees was approximately $833 \mathrm{~mm}$ (Dzikiti et al., 2016). Dye and

TABLE 1

Aggregated monthly values of selected daily weather variables measured at La Motte farm near Franschhoek town

\begin{tabular}{|l|c|c|c|c|c|c|c|c|c|c|c|c|c|}
\hline Month/variable & Feb-'15 & Mar-'15 & Apr-'15 & May-'15 & Jun-'15 & Jul-'15 $^{\prime}$ & Aug-'15 $^{\prime}$ & Sep-'15 & Oct-'15 & Nov-'15 & Dec-'15 & Jan-'16 $^{\prime}$ & Feb-'16 \\
\hline Rainfall $(\mathrm{mm})$ & 7.0 & 5.7 & 10.4 & 70.4 & 160.8 & 164.0 & 70.4 & 25.7 & 6.7 & 33.8 & 28.5 & 12 & 7.5 \\
\hline Daily max. T $\left({ }^{\circ} \mathrm{C}\right)$ & 29.3 & 30.2 & 26.4 & 22.2 & 18.5 & 16.9 & 19.5 & 21.5 & 26.4 & 27.0 & 30.6 & 39.6 & 38.3 \\
\hline Daily min. T $\left({ }^{\circ} \mathrm{C}\right)$ & 15.6 & 16.3 & 12.8 & 11.2 & 7.8 & 7.7 & 9.6 & 10.6 & 12.4 & 13.1 & 16.1 & 15.5 & 11.7 \\
\hline $\begin{array}{l}\text { Daily solar rad. } \\
\left(\mathrm{MJ} \cdot \mathrm{m}^{-2} \cdot \mathrm{d}^{-1}\right)\end{array}$ & 24.3 & 20.2 & 15.3 & 8.8 & 7.5 & 8.0 & 10.3 & 12.9 & 19.0 & 23.8 & 28.4 & 27.5 & 24.3 \\
\hline $\begin{array}{l}\text { Daily wind speed } \\
\left(\mathrm{m} \cdot \mathrm{s}^{-1}\right)\end{array}$ & 1.1 & 1.1 & 1.0 & 0.6 & 0.7 & 0.8 & 0.7 & 1.0 & 0.8 & 0.9 & 0.9 & 1.1 & 1.0 \\
\hline
\end{tabular}

TABLE 2

Weighting of observed transpiration volumes in 3 P. canescens trees relative to stem diameter variation within the stand, to determine a representative total water-use

\begin{tabular}{|c|c|c|c|c|c|c|}
\hline Stem DBH size classes $(\mathrm{cm})$ & $\begin{array}{l}\text { No. of trees in } \\
\text { sub-sample }\end{array}$ & HPV tree no. & $\begin{array}{l}\text { HPV tree stem } \\
\text { DBH }(\mathrm{cm})\end{array}$ & $\begin{array}{c}\text { 1-yr water-use } \\
\left(\text { L.tree }{ }^{-1}\right)\end{array}$ & $\begin{array}{l}\text { 1-yr water-use } \\
(\mathrm{mm})\end{array}$ & Weighting \\
\hline$\leq 10 \mathrm{~cm}$ & 19 & 2 & 9.2 & 3082 & 287.6 & $33.9 \%$ \\
\hline $10-20 \mathrm{~cm}$ & 18 & 1 & 16.2 & 1016 & 94.8 & $32.2 \%$ \\
\hline$\geq 20 \mathrm{~cm}$ & 19 & 3 & 24.0 & 6641 & 619.6 & $33.9 \%$ \\
\hline Weighted total for stand & & & & 3625 & 338.3 & $100.0 \%$ \\
\hline
\end{tabular}



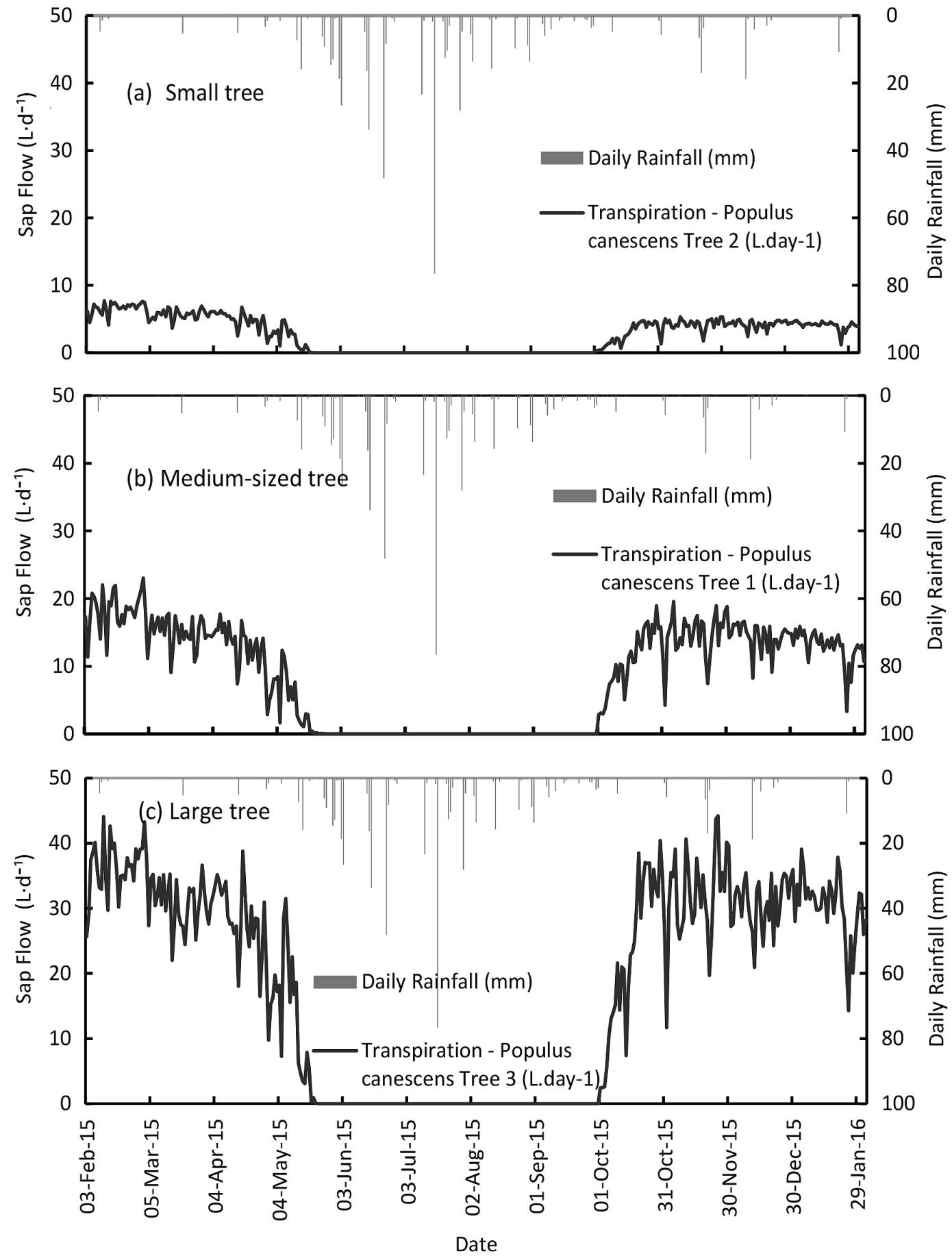

Figure 3

Daily sap flow volumes recorded in riparian P. canescens tree at Franschhoek with small (a), medium (b), and large (c) stem sizes

Jarmain (2004) recorded annual transpiration rates of Acacia mearnsii (Black Wattle) invasions, also in the Western Cape, amounting to $1503 \mathrm{~mm}$, while a similar value $(\sim 1500 \mathrm{~mm})$ was reported for Saltcedar invasions in Australia by Doody et al. (2011) (Table 3). Doody and Benyon (2011) measured annual transpiration rates of up to $2410 \mathrm{~mm}$ on Salix babylonica (Weeping Willow) invasions growing along a stream channel in Australia. These figures illustrate that riparian invasions have the ability to use large quantities of water and therefore potentially have adverse effects on the water resources.
The relatively low water use by the poplars is a result of the deciduous nature of the species while the prevalence of young trees at our study site may have a played a role, among other factors. Regarding the drivers of transpiration for the poplars, the daily transpiration was strongly correlated to daily solar radiation $\left(R^{2}>0.81\right)$ (Fig. 4a), suggesting that radiation was not a limiting factor for water use by this species.

However, the vapour pressure deficit of the air (VPD) limited transpiration and substantial reductions occurred at VPDs higher than $1.5 \mathrm{kPa}$ (Fig 4b). Transpiration was poorly correlated 

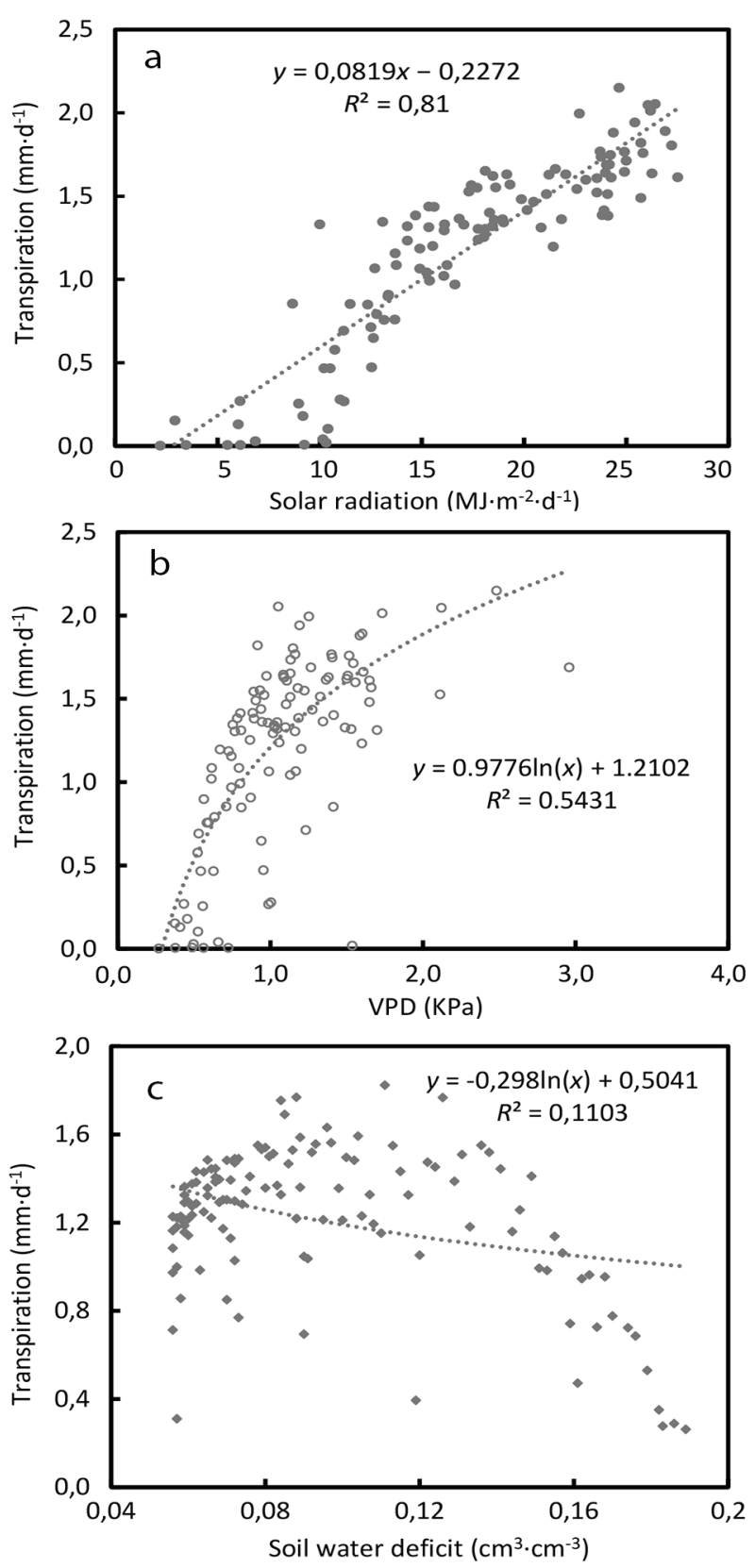

Figure 4

Effect of: (a) daily solar radiation, (b) average VPD, and (c) soil water deficit on the daily transpiration of the riparian poplar trees to the soil water deficit at the $15 \mathrm{~cm}$ depth, given that the trees likely accessed river water (Fig. 4c). As expected the soil water content levels closely followed rainfall events, climbing from 5\% in summer to a maximum of $26 \%$ in winter (July) (Fig 5).

\section{Leaf area index, forest floor evaporation and stand evapotranspiration}

For the August 2015 survey the P. canescens trees had no leaves, and so the leaf area index was zero. For the second campaign on 6 October 2015, the leaves of the trees were rapidly expanding and the stand LAI was $1.8 \mathrm{~m}^{2} \cdot \mathrm{m}^{-2}$. Transpiration, soil and open water evaporation measurements indicated partitioning of the evaporative fluxes during a phase of active leaf growth. The last two sets of measurements took place when the trees were at their maximum canopy cover (LAI $\sim 2.3 \mathrm{~m}^{2} \cdot \mathrm{m}^{-2}$ ).

The diurnal trends in the open water evaporation were influenced by both the climatic conditions and by shading by the tree canopies (Fig. 6a). The summer measurements (December and February) recorded the highest open water evaporation rates with peaks higher than $1.0 \mathrm{~mm} \cdot \mathrm{h}^{-1}$ around midday. Evaporation in August was also high, peaking at $0.7 \mathrm{~mm} \cdot \mathrm{h}^{-1}$ due to lack of shading when the trees had no leaves. Open water evaporation was lowest in the October campaign, peaking at less than $0.4 \mathrm{~mm} \cdot \mathrm{h}^{-1}$ when the atmospheric evaporative demand was relatively low and there was considerable shading of the water surface. Hourly forest-floor evaporation followed the course of the atmospheric evaporative demand in all of the campaigns (Fig. 6b). It appears that there were no significant differences in the hourly soil evaporation trends for all the surveys with maximum values of $0.5 \mathrm{~mm} \cdot \mathrm{h}^{-1}$. Assuming that the open water in the stream occupied approximately $15 \%$ of the study area, with canopy cover of $0 \%$ in late winter (August 2015) and approximately $65 \%$ during the summer campaigns (estimated from the stand LAI), the bare soil fraction was therefore about $85 \%$ in August and $20 \%$ during the summer months. The daily evapotranspiration, calculated as the weighted total of evaporation from the soil, open water, and tree transpiration, was therefore $2.1 \mathrm{~mm}$ in August 2015, $0.96 \mathrm{~mm}$ in October 2015, $2.0 \mathrm{~mm}$ in December 2015 and $1.61 \mathrm{~mm}$ in February 2016. The reference evapotranspiration for these days was $2.19 \mathrm{~mm}$ in August, $3.38 \mathrm{~mm}$ in October, $6.63 \mathrm{~mm}$ in December, and $5.78 \mathrm{~mm}$ in February. Based on the above estimates, the contributions of the open-water and forest-floor evaporation to stand-level ET were, respectively, 8 and 92\% in August. Soil evaporation, open-water evaporation, and transpiration were, on average, 33,17 and $50 \%$ of stand ET during the summer months.

\begin{tabular}{|l|c|l|l|l|l|}
\hline \multicolumn{7}{|c|}{ TABLE 3 } \\
A summary of the annual transpiration rates of various IAP species in riparian and non-riparian settings \\
\hline Species & $\begin{array}{c}\text { Transpiration } \\
\text { in } \mathbf{m m} \cdot y r-1\end{array}$ & Measurement method & Location & Country & Reference \\
\hline Black Wattle & 1503 & Heat ratio sap flow method & Riparian & South Africa & Dye \& Jamain, 2004 \\
\hline Saltcedar & 1500 & Heat ratio sap flow method & Riparian & Australia & Doody et al., 2011 \\
\hline Salix Babylonica & 2410 & Heat ratio sap flow method & Riparian & Australia & Doody \& Benyon, 2011 \\
\hline Pine halepinsis & 980 & Heat ratio sap flow method & Riparian & South Africa & Dzikiti et al., 2013 \\
\hline Melastoma septemnervium & 265 & Heat dissipation sap flow method & Upland & Hawaii, USA & Cavaleri et al., 2014 \\
\hline Pinus radiata & 902 & Heat ratio sap flow method & Upland & Australia & Benyon \& Doody, 2015 \\
\hline Eucalyptus camaldulensis & 833 & Heat ratio sap flow method & Riparian & South Africa & Dzikiti et al., 2016 \\
\hline Eucalyptus globulus & 670 & Heat ratio sap flow method & Upland & Australia & Benyon \& Doody, 2015 \\
\hline Prosopis spp. & 544 & Heat ratio sap flow method & Upland & South Africa & Dzikiti et al., 2017 \\
\hline
\end{tabular}




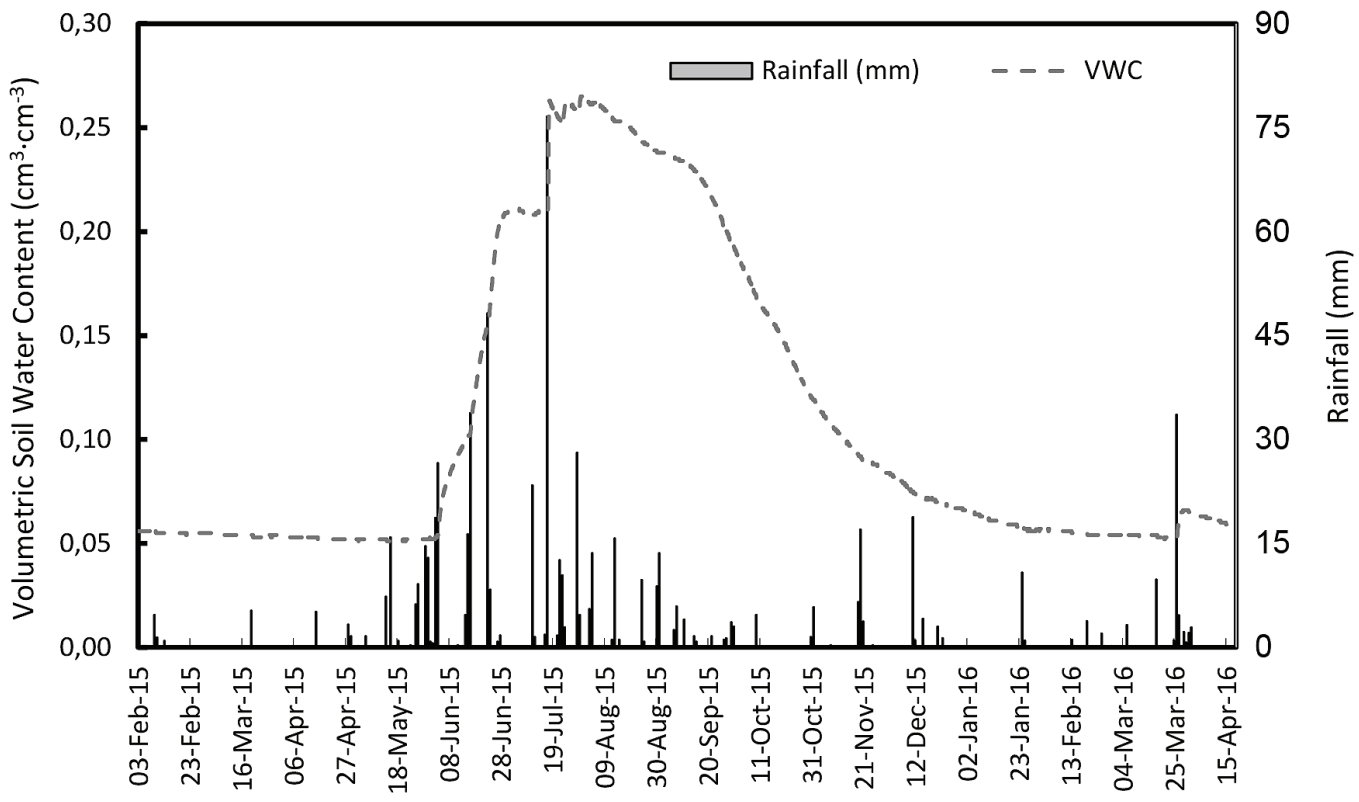

Figure 5

Fluctuations in volumetric soil water content (VWC) measured in the root zone of P. canescens trees at Franschhoek between February 2015 and January 2016
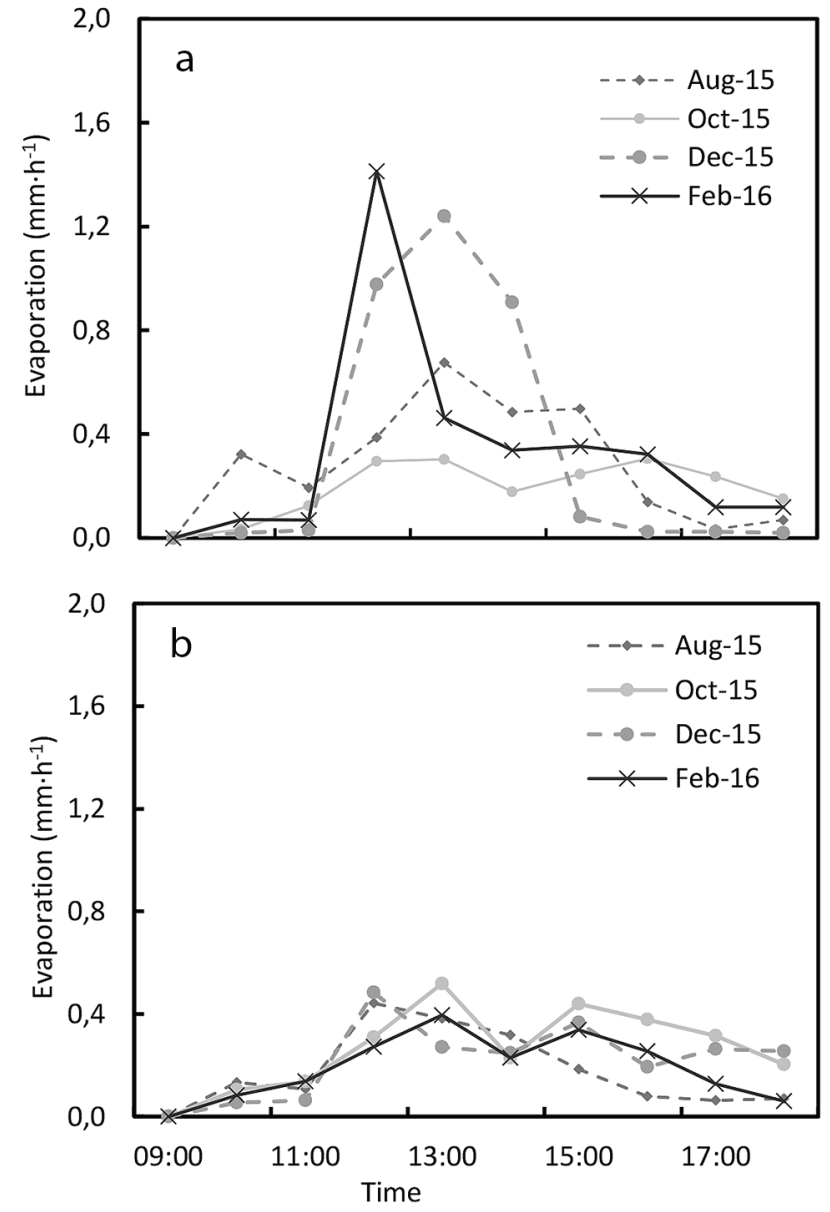

Figure 6

(a) The diurnal course of evaporation from the forest floor at the P. canescens site, on 4 occasions, and (b) diurnal open water evaporation from the river during the same 4 occasions

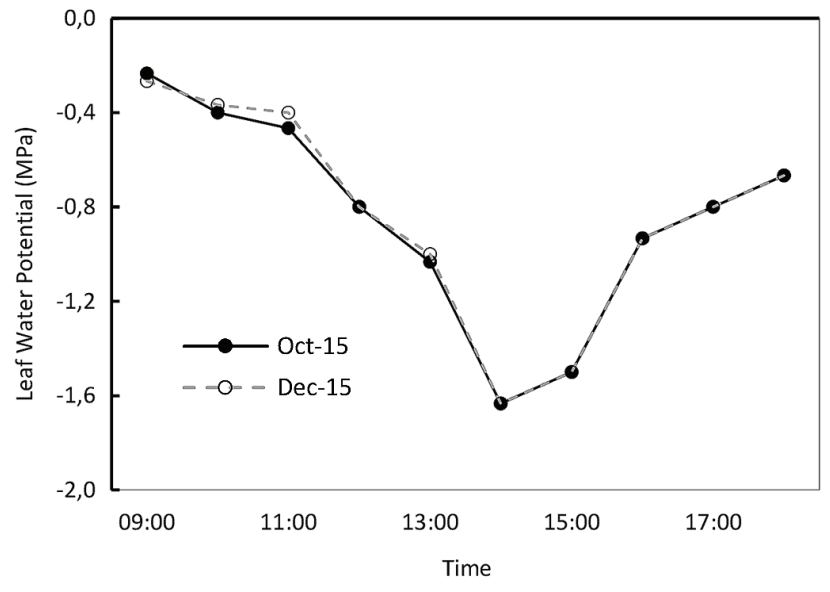

Figure 7

The diurnal course of the water status of the P. canescens trees depicted by the leaf water potential

\section{Leaf water potential and tree hydraulic resistances}

There were no significant differences $(\mathrm{p}<0.01)$ in the diurnal water status of the poplar invasions for data collected in October 2015, December 2015 and February 2016 (Fig. 7). Differences in the water status were compared between the three surveys using one-way analysis of variance. The midday leaf water potential dropped to $-1.6 \mathrm{MPa}$. If the data are extrapolated backwards (Fig. 7), it is clear that predawn leaf water potential was less than $-0.4 \mathrm{MPa}$, suggesting that the trees had access to ample water.

The midday depression in the leaf water potential was therefore a reflection of the imbalance between water uptake by the roots and transpiration by the leaves (in phase with the atmospheric evaporative demand), and this is a function of the hydraulic properties of the trees. We therefore used the sap flow 
$\left(F\right.$, in $\left.g \cdot h^{-1}\right)$ and leaf water potential $(\psi$ in $\mathrm{MPa})$ data to estimate the whole plant hydraulic resistance $\left(R_{x}\right.$, in MPa $\left.\cdot h \cdot \mathrm{g}^{-1}\right)$. The hydraulic resistance gives an indication of the efficiency with which the hydraulic system transports water from the roots to the leaf stomata. According to Jones (1992), a simple Ohm's law analogue can be used to relate the stem sap flow rate to the water status of the trees, such that:

$$
F=\frac{\psi_{s}-\psi_{l}}{R_{x}}
$$

where $\psi_{s}$ is the soil water potential. Given that the trees showed no signs of water stress and likely had access to river water throughout the year, we assumed that the soil water potential in the active root zone was zero. So the graph of stem sap flow $(F)$ vs. the leaf water potential has a slope of $-1 / R_{x}$. Typical hydraulic resistances for $P$. canescens trees scaled with stem size (Table 4). Larger trees had a low hydraulic resistance of 1.4 MPa $\cdot h \cdot g^{-1}$ while smaller trees had high resistances of up to $14.3 \mathrm{MPa} \cdot \mathrm{h} \cdot \mathrm{g}^{-1}$.

These values are more than 10 times higher than those presented for the same species by Zhang et al. (1999) in the maritime temperate climate in England. This suggests that although the trees had ready access to water, the hydraulic system likely limited the volumes of water that could be transported through the transpiration stream at a given time. The difference in the hydraulic resistances was probably due to climatic differences between the sites, as suggested by Pfautsch et al. (2016), and possibly differences in the wood anatomy. As a result of the high hydraulic resistances, the time lags between water uptake by the roots and transpiration by the small trees was around $1 \mathrm{~h}$ while it was between 1 and $2 \mathrm{~h}$ for the large trees (Fig. 8). Up to $15 \%$ of the daily transpiration of the $P$. canescens trees was water withdrawn from the internal storage pools early in the day (Fig. 9).

But this water was subsequently replaced as evidenced by stem sap flow which continued well after sunset, only stopping after 22:00 (Fig. 9).

To accurately quantify the impacts of the invasions on the water resources, information on the incremental water use by $P$. canescens over and above that used by the indigenous vegetation that would replace the invasions once cleared is needed (Dzikiti et al., 2016; Scott-Shaw et al., 2017). Water use by the co-occurring indigenous vegetation in the study area was not quantified in this study. However, the transpiration rates by the $P$. canescens trees were very low compared to the other riparian species, such that the incremental water use will likely be negligible.

\section{CONCLUSIONS}

This study shows that $P$. canescens invasions growing along a river channel in the Western Cape have a fairly conservative impact on the water resources. Reasons for the low water-use

TABLE 4

Effect of tree size on the hydraulic resistance of riparian P. canescens invasions

\begin{tabular}{|l|c|}
\hline Stem DBH $(\mathrm{cm})$ & $\mathbf{R}_{\mathbf{x}}\left(\mathrm{MPa} \cdot \mathbf{h} \cdot \mathbf{g}^{-1}\right)$ \\
\hline$\leq 10 \mathrm{~cm}$ & 14.25 \\
\hline $10-20 \mathrm{~cm}$ & 4.49 \\
\hline$\geq 20 \mathrm{~cm}$ & 1.38 \\
\hline
\end{tabular}
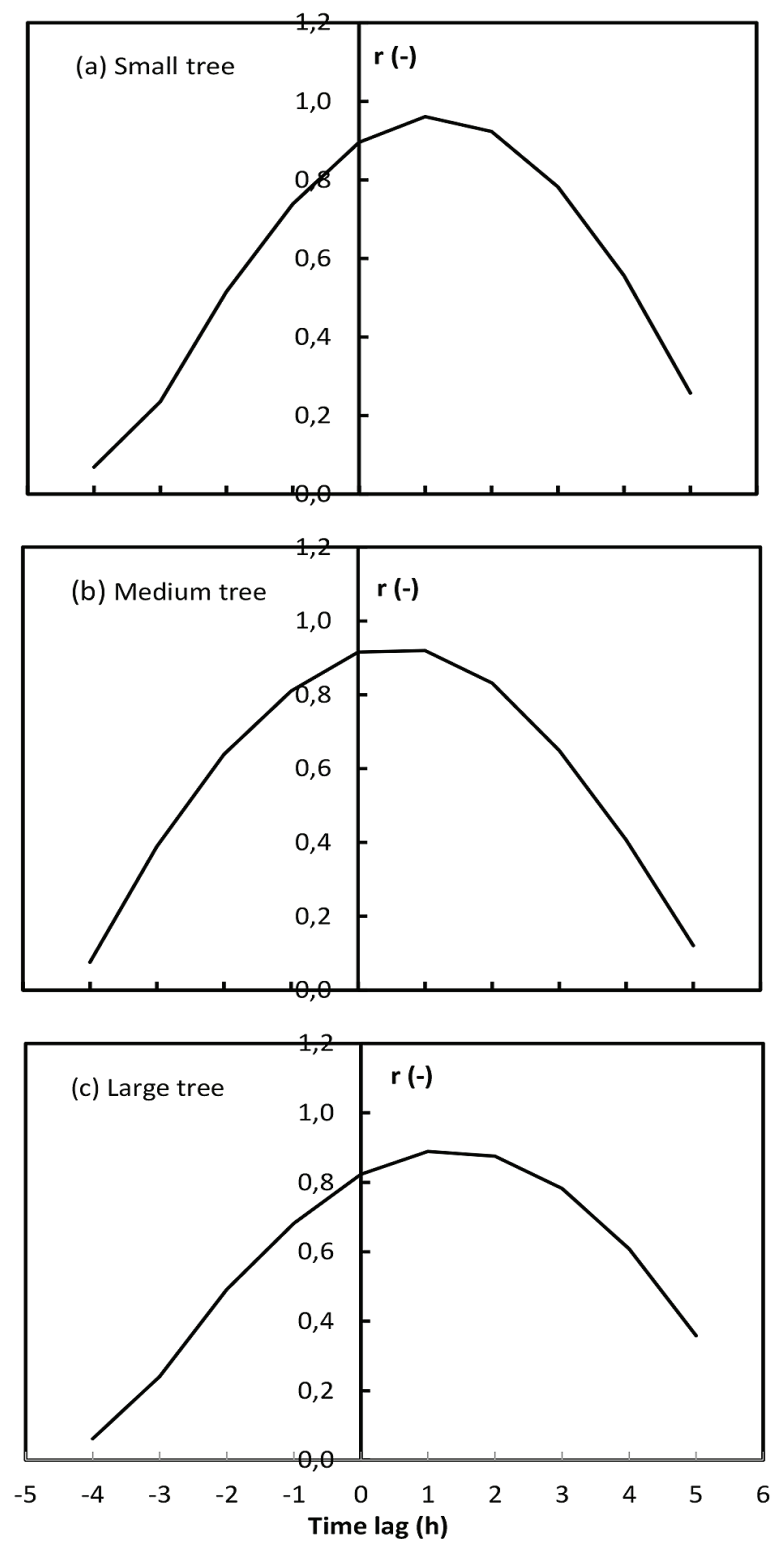

Figure 8

Time lags between water uptake (stem sap flow) and water loss (transpiration) for P. canescens trees of different sizes

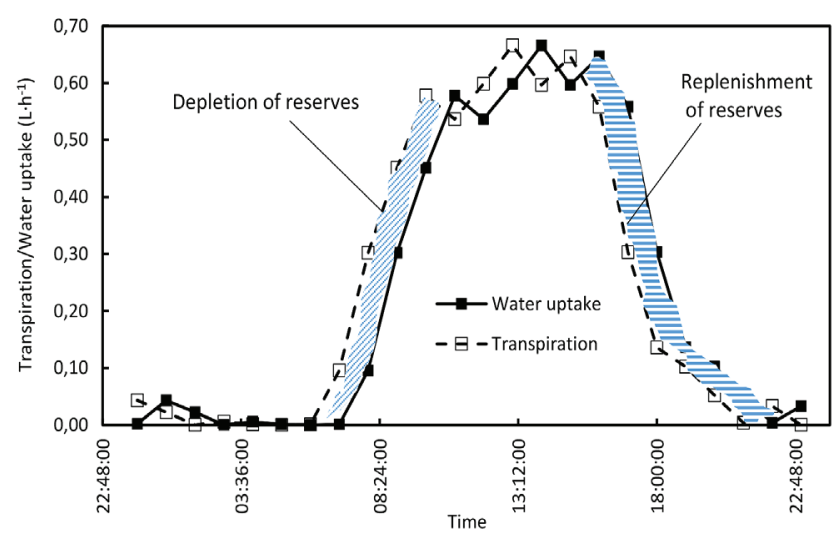

Figure 9

Relationship between leaf transpiration and root water up take for a riparian P. canescens tree 
rates include the deciduous nature of the species. This shortens the length of the transpiring period leading to reduced seasonal transpiration totals. Another possible reason is the high hydraulic resistance in the transpiration stream of $P$. canescens, which limits the quantities of water that can transported from the roots to the shoots at a given time. Reasons for the high hydraulic resistances are unclear, although the prevailing environmental conditions may have played a role. Given the low water use rates of $P$. canescens, this species could receive a low priority in alien plant clearing programmes aimed at salvaging water.

\section{ACKNOWLEDGEMENTS}

We would like to thank the Working for Water programme in the Department of Environmental Affairs for sponsoring this research. Additional funding from the CSIR's Parliamentary grant (Project no ECHS 043) is also acknowledged. The helpful cooperation of Mr Francois Malherbe is gratefully acknowledged for allowing the research to be carried out on his farm, Eikenhof. Lastly, we gratefully acknowledge the Agricultural Research Council for providing the weather data.

\section{REFERENCES}

ALLEN RG, PEREIRA LS, RAES D and SMITH M (1998) Crop evapotranspiration: guidelines for computing crop water requirements. Irrigation and Drainage Paper 56. United Nations FAO, Rome.

BENYON RG and DOODY TM (2015) Comparison of interception, forest floor evaporation and transpiration in Pinus radiata and Eucalyptus globulus plantations. Hydrol. Process. 29 1173-1187. https://doi.org/10.1002/hyp.10237

BURGESS SO, ADAMS M, TURNER N and BEVERLY C (2001) An improved heat pulse method to measure low and reverse rates of sap flow in woody plants. Tree Physiol. 21 589-598. https://doi. org/10.1093/treephys/21.9.589

CALDER I, and DYE P (2001) Hydrological impacts of invasive alien plants. Land Use Water Resour. Res. 7 1-12.

CAVALERI MA, OSTERTAG R, CORDELL S and SACK L (2014) Native trees show conservative water use relative to invasive trees: results from a removal experiment in a Hawaiian forest. Conserv. Physiol. http://dx.doi.org/10.1093/conphys/cou016.

CLULOW AD, EVERSON CS and GUSH MB (2011) The long-term impact of Acacia mearnsii trees on evaporation, stream flow, and ground water resources. WRC Report No. TT 505/11. Water Research Commission, Pretoria.

DOODY TM and BENYON RG (2011) Quantifying water savings from willow removal in Australian streams. J. Environ. Manag. 92 926-935. https://doi.org/10.1016/j.jenvman.2010.10.061

DOODY TM, NAGLER PL, GLENN EP, MOORE GW, MORINO K, HULTINE KR and BENYON RG (2011) Potential for water salvage by removal of non-native woody vegetation from dryland river systems. Hydrol. Process. 25 4117-4131. https://doi.org/10.1002/ hyp. 8395

DYE P and JARMAIN C (2004) Water use by black wattle (Acacia mearnsii): implications for the link between removal of invading trees and catchment streamflow response. S. Afr. J. Sci. 100 40-44.

DYE PJ and VERSFELD DB (2007) Managing the hydrological impacts of South African plantation forests: and overview. For. Ecol. Manage. 251 121-128. https://doi.org/10.1016/j.foreco.2007.06.013

DYE PJ, JARMAIN C, LE MAITRE D, EVERSON C, GUSH M and CLULOW A (2008) Modelling vegetation water use for general application in different categories of vegetation. WRC Report No. 1319/1/08. Water Research Commission, Pretoria.

DZIKITI S, SCHACHTSCHNEIDER K, NAIKEN V, GUSH M and LE MAITRE DC (2013a) Comparison of water use by alien invasive pine trees growing in riparian and non-riparian zones in the Western Cape, South Africa. For. Ecol. Manage. 293 92-102. https:// doi.org/10.1016/j.foreco.2013.01.003

DZIKITI S, SCHACHTSCHNEIDER K, NAIKEN V, GUSH M and MOSES G (2013b). Water relations and the effects of clearing invasive Prosopis trees on groundwater in an arid environment in the Northern Cape, South Africa. J. Arid Environ. 90 103-113. https://doi.org/10.1016/j.jaridenv.2012.10.015

DZIKITI S, GUSH MB, LE MAITRE DC, MAHERRY A, RAMOELO A and JOVANOVIC NZ (2016) Quantifying potential water savings from clearing invasive alien Eucalyptus camaldulensis using in situ and high resolution remote sensing data in the Berg River Catchment, Western Cape, South Africa. For. Ecol. Manage. J. 361 69-80. https://doi.org/10.1016/j.foreco.2015.11.009

DZIKITI S, NTSHIDI Z, LE MAITRE D, BUGAN RDH, MAZVIMAVI D, SCHACHTSCHNEIDER K, JOVANOVIC NZ and PIENAAR HH (2017) Assessing water use by Prosopis invasions and Vachellia karroo trees: Implications for groundwater recovery following alien plant removal in an arid catchment in South Africa. For. Ecol. Manage. J. 398 153-163. https://doi. org/10.1016/j.foreco.2017.05.009

GUSH MB, SCOTT DF, JEWITT GPW, SCHULZE RE, LUMSDEN TG, HALLOWES LA and GÖRGENS AHM (2002) Estimation of streamflow reductions resulting from commercial afforestation in South Africa. WRC, Pretoria, RSA. WRC Report No. TT 173/02. Water Research Commission, Pretoria. 136 pp.

JONES HG (1990) Plant water relations and implications for irrigation scheduling. Acta Hortic. 278 67-76. https://doi.org/10.17660/ ActaHortic.1990.278.4

JONES HG (1992) Plants and Microclimate. Cambridge University Press, Cambridge. 428 pp.

LE MAITRE DC, VERSFELD DB and CHAPMAN RA (2000) The impact of invading alien plants on surface water resources in South Africa: A preliminary assessment. Water SA 26 397-408.

LE MAITRE DC, FORSYTH GG, DZIKITI S and GUSH MB (2016) Estimates of the impacts of invasive alien plants on water flows in South Africa. Water SA 42 659-672. http://dx.doi.org/10.4314/wsa. v42i4.17

MIDGLEY GF, HANNAH L, MILLAR D, THUILLER W and BOOTH A (2003) Developing regional and species-level assessments of climate change impacts on biodiversity: a preliminary study in the Cape Floristic Region. Biol. Conserv. 112 87-97. https://doi. org/10.1016/S0006-3207(02)00414-7

NTSHIDI Z, DZIKITI S, MAZVIMAVI D, BUGAN RBH, LE MAITRE DC, GUSH MB and JOVANOVIC NZ (2015) Comparative use of groundwater by invasive alien Prosopis spp. and co-occurring indigenous $V$. karroo in a semi-arid catchment. Paper presented at: $14^{\text {th }}$ Biennial Ground Water Division Conference and Exhibition, 21-23 September 2015, Muldersdrift, South Africa.

PFAUTSCH S (2016) Hydraulic anatomy and function of trees-basics and critical development. Curr. For. Rep. 2 236-248. https://doi. org/10.1007/s40725-016-0046-8

RICHARDSON DM and VAN WILGEN BW (2004) Invasive alien plants in South Africa: how well do we understand the ecological impacts? S. Afr. J. Sci. $10045-52$.

SCOTT DF and PRINSLOO FW (2008) Longer-term effects of pine and eucalypt plantations on streamflow. Water Resour. Res. 44 (7) https://doi.org/10.1029/2007WR006781

SCOTT-SHAW BC, EVERSON CS and CLULOW AD (2017) Wateruse dynamics of an alien invaded riparian forest within the Mediterranean climate zone of the Western Cape, South Africa. Hydrol. Earth Syst. Sci. 21 4551-4562. https://doi.org/10.5194/ hess-21-4551-2017

STEPPE K, DZIKITI S, LEMEUR R and MILFORD JR (2006) Stomatal oscillations in orange trees under natural climatic conditions. Ann. Bot. 92 831-835. https://doi.org/10.1093/aob/mcl031

SWANSON RH and WHITFIELD DWA (1981) A numerical analysis of heat pulse velocity theory and practice. J. Exp. Bot. 32 221-239. https://doi.org/10.1093/jxb/32.1.221 
VAN WILGEN BW, RICHARDSON DM, LE MAITRE DC, MARAIS C and MAGADLELA D (2001) The economic consequences of alien plant invasions: Examples of impacts and approaches to sustainable management in South Africa. Environ. Dev. Sustainability 3 145168. https://doi.org/10.1023/A:1011668417953

VAN WILGEN BW, FORSYTH GG and LE MAITRE DC (2008) The prioritization of species and primary catchments for the purposes of guiding invasive alien plant control operations in the terrestrial biomes of South Africa. CSIR Report CSIR/NRE/ECO/ ER/2008/0070/C. CSIR, Pretoria.
WULLSCHLEGER SD and KING AW (2000) Radial variation in sap velocity as a function of stem diameter and sapwood thickness in yellow-poplar trees. Tree Physiol. 20 511-518. https://doi. org/10.1093/treephys/20.8.511

ZHANG H, MORISON JIL and SIMMONDS LP (1999) Transpiration and water relations of poplar trees growing close to the water table. Tree Physiol. 19 563-573. https://doi.org/10.1093/treephys/19.9.563 
CORRIGENDUM (16 July 2018)

Corrigendum for Water SA 44 (2) 328-337, originally published in April 2018:

Table 2, p. 331, should be replaced by Table 2 below. Please note that the values for water use (Columns 5 and 6 ) have been swapped between the first two stem size classes. This was a transcription error and does not affect the findings reported in the rest of the paper:

Table 2

Weighting of observed transpiration volumes in $3 \mathbf{P}$. canescens trees relative to stem diameter variation within the stand, to determine a representative total water-use

\begin{tabular}{|l|c|c|c|c|c|c|}
\hline $\begin{array}{l}\text { Stem DBH } \\
\text { size classes } \\
\text { (cm) }\end{array}$ & $\begin{array}{c}\text { No. of trees in } \\
\text { sub-sample }\end{array}$ & $\begin{array}{c}\text { HPV } \\
\text { tree no. }\end{array}$ & $\begin{array}{c}\text { HPV tree } \\
\text { stem DBH } \\
\text { (cm) }\end{array}$ & $\begin{array}{c}\text { 1-yr water-use } \\
\left(\mathbf{L} \cdot \text {-tree }^{-1}\right)\end{array}$ & $\begin{array}{c}\text { 1-yr water-use } \\
\text { (mm) }\end{array}$ & Weighting \\
\hline$\leq 10 \mathrm{~cm}$ & 19 & 2 & 9.2 & 1016 & 94.8 & $33.9 \%$ \\
\hline $10-20 \mathrm{~cm}$ & 18 & 1 & 16.2 & 3082 & 287.6 & $32.2 \%$ \\
\hline$\geq 20 \mathrm{~cm}$ & 19 & 3 & 24.0 & 6641 & 619.6 & $33.9 \%$ \\
\hline \multicolumn{2}{l}{ Weighted total for stand } & & $\mathbf{3 6 2 5}$ & $\mathbf{3 3 8 . 3}$ & $\mathbf{1 0 0 . 0 \%}$ \\
\hline
\end{tabular}

